Pakistan Journal of Social Sciences 7 (3): 244-253, 2010

ISSN: $1683-8831$

(C) Medwell Journals, 2010

\title{
The Programme of Urban Renewal for Sustainable Urban Development in Nigeria: Issues and Challenges
}

\author{
J.T. Gbadegesin and B.T. Aluko \\ Department of Estate Management, Obafemi Awolowo University, \\ Ile-Ife, Osun State, Nigeria
}

\begin{abstract}
The rampage of hooliganism, criminality, housing problems, infrastructural decay, social vices, environmental degradation and traffic congestion have been considered outcomes of rapid population growth and tremendous pressure on civic infrastructure systems. Urban renewal is perceived to play an important role in the policy towards sustainable development of cities. The study achieves this through a literature review of urban renewal programmes and draws out implications for effective urban renewal programme in Nigeria.
\end{abstract}

Key words: City, Nigeria, sustainable development, urban decay, urban renewal, hetrogeneous

\section{INTRODUCTION}

For centuries, cities have been the heart, the lifeblood of various civilizations, the epicenter of economic, political and artistic activities (Spates and Macionis, 1987). Cities as seen today exert an increasing attraction on people worldwide in fact, the population tends to concentrate in big cities. Gomez and Salvador (2006) opined that in the 21 st century the number of people living in cities will progressively increase. City is not an artificial construct; the city is a set of habits, customs and lifestyles. These elements are interrelated and rather than being viewed individually, they are subsumed in the identity of place and the identification of the city (Sepe, 2006). According to the researcher, the contemporary city is characterized by complexity, simultaneity and instability, producing situations of transience and transformation.

In the developed countries in Europe and America, transformations have contributed to an increasing urban identity crisis which transformed cities into heterogeneous. The mutations in interpersonal relationships and intergeneration gaps, technological development, mass migrations and globalization have transformed to spaces in the urban landscape; new types of place have arisen and the utilization of existing spaces has been modified (Sepe, 2006; Gospodini, 2002, 2004).

Urban cities occupy only a small part of the territory; actually cities occupy $2 \%$ of the surface area of the territory (Gomez and Salvador, 2006; Terradas, 2001). However, each city has its own history marked by the way it extended and grew thus it is not surprising to find cities that expanded and occupied new land even in periods in which the population was decreasing.

Urban phenomenon is continuously increasing, extending the boundaries of the city or metropolitan areas. Thus, urban planning is experiencing a crisis at least the concept of urban planning that appeared with the modern movement and its myriad of architects. The reality in the big cities in Nigeria such as Lagos, Ibadan, Port Harcourt and Benin presents a number of problems that are worth mentioning. These include urban decay, slum, overcrowding, lawlessness; invasion of periurban spaces causes the loss of land and natural resources. The basis of the urban crisis lies in the dimensions and expansion of the large cities where these problems become even more severe. For instance 42 slum communities or blighted areas were identified in Lagos metropolis in 1981 by a World Bank Urban Renewal project. The number of slums in the city is estimated to have increased to about 100 due to the inadequacy of private public institutions to provide housing the increasing population (Adelekan, 2004).

Inadequacy of basic infrastructures in the urban centres in many African cities, poor urban planning together with other urban governance challenges contributes to making African urban slum dwellers works at risk. Poor urban planning or lack of planning as urban development increases is evident in not preventing new development on areas at risk of flooding (Adelekan, 2004). According to McGianahan et al. (2007), economic activity and urban development often increase the environmental pressures that lead to flooding and slum. The foregoing

Corresponding Author: J.T. Gbadegesin, Department of Estate Management, Obafemi Awolowo University, Ile-Ife, Osun State, Nigeria 
provokes the scholars investigation into the issues of urban regeneration as a tool for sustaining urban development. The objectives of the study are to examine the level of urbanization in Nigeria, concept of sustainable development; identify and examine the phases of urban decay in the system, examine issues of urban renewal/ development for urban sustainability and strategies and identity the challenges of urban renewal in Nigeria.

\section{MATERIALS AND METHODS}

Level of urbanization in Nigeria: Urban areas are central to the demographic, economic and environmental challenge of the 21 st century (UN and UNCHs, 2010). The size, form, structure and function of urban areas and their future growth are critical elements in the transaction to global sustainability. Urban centres worldwide are perceived as center of excellence, centres of opportunities where aspirations and desires are met (Ademiluyi and Solanke, 2008).

Mabogunje (1980) posited that urban centres are more populous and more complex in terms of socio-economic activities and opportunities. An urban centre is a place where all opportunities abound which necessitates the pace of rural-urban migration. Oyesiku (1997) described urban centres as places of economic strength, power development, movation and modern culture. It is the point of concentration of socio-economic facilities.

The phenomenon of contemporary urbanization has evoked considerable interest of scholars in social sciences including geography (Phillip and Leo, 1985). The present day worldwide growth of cities-an unprecedented increase in number and size of cities is a fundamental phenomenon of the modern times with far reaching consequences for human life and civilization. Increase of urban population relative to that of rural component within an area suggests concentration. Urbanization via demographic approach is seen as a process of population concentration which according to Hope Tisdale Eldridge, advances along two dimensions; the multiplication of points of concentration and the increase in the size of individual concentrations.

The urbanization level for any nation is the proportion of national population living in urban centres. Cities constitute masses of people concentrated in varying degrees. Their growth and dynamism are inseparably bounding with anabatic concentration, a process resulting from migration of rural populace to urban centres and increase of the urban population (Onard, op. cit.). The population of Nigeria reveals a classic example of rapid growth and explosion

\begin{tabular}{lcc}
\multicolumn{2}{l}{ Table 1: Nigerian population $1921-2020$} \\
Total \\
Years & $18,720.0$ & $\begin{array}{c}\text { Urban population as \% } \\
\text { of total population }\end{array}$ \\
\hline 1921 & $20,056.0$ & 4.8 \\
1922 & $30,402.0$ & 6.7 \\
$1952 / 54$ & $55,670.0$ & 10.2 \\
1963 & $78,924.0$ & 19.2 \\
1972 & $96,684.0$ & 25.1 \\
1991 & 120.0 & 33.0 \\
2002 & 140.0 & 42.0 \\
2006 & $160,000.0$ & $*$ \\
2020 & & 68.0
\end{tabular}

(Ademiluyi and Solanke, 2008). By estimation in year 2002, Nigerian population was about 120 million and would be about 160 million in 2020. According to (UNECA), the nation experienced estimated increases of $33 \%$ in the decades. As far as Nigeria is concerned, Nigeria 4.8\% urbanized in 1921, it was moved to $10.2 \%$ between 1952 and 1954. It further increased to $19.2 \%$ in 1963 and jumped to $42 \%$ in 2002 , estimation however suggests further increase to about $68 \%$ by 2020 . Table 1 shows the summary of the incidence of urbanization in Nigeria.

The foregoing phenomenon has necessitated undue pressure in infrastructures systems in many ways such as; over-stretched urban infrastructures, massive urban environmental degradation, urban floodingand deforestation as more settlements constructed (Igbokwe, 2006). Therefore, a grand idea to revitalize city centres as an opportunity to start up a process of new urbanization that awards cities a specific and important role cannot be overemphasized.

Concept of sustainability of urban development: The term sustainable development has been viewed from different perspective. The World Food Programme (WFP) defines it thus to allow for future generation requires that we preserve the remaining resources and that we had or rehabilitate resources that have been treated carelessly in the past.

Sustainable development sprang from the roots of modern economics as Malthus and Ricardo had forseen natural limits to economic growth. The report given by the World Conference on Environment and Development (WCED) known as Bruntland Commission has resulted to the usage of the concept Sustainable Development internationally (Alao, 1995). The commission thus defined it as a process of change in which the exploitation of resources, the direction of investments, the orientation of technological development and institutional change are all in having and enhance both current and future potential to meet human needs and aspirations.

Akinbode (1995) described sustainable development in general term as the provision of adequate and affordable basic needs of life for the present generation 
without jeopardizing the prospects of subsequent generations. Sustainable development, therefore is a notion, a movementand an approach which has developed into a global wave of concerns, study, political mobilization and organization around the turn issues of environmental protection and economic development. Perhaps the most recent popularization of the notion of sustainable development can be found in the report of the World Commission on Environment and Development (WCED) titled the common future. The report elevated the notion of principles, ideals and values seen as desirable and necessary if the world is to deal effectively with current global problems of the environment and the development process. The approach embodies the notion and ideal of a development process that is equitable and socially responsive, recognizing the extensive nature of poverty, deprivationand inequality between and within nations, classes and communities.

Goodwillie and Webb Described sustainable development as a process of change in which the exploitation of resources, the direction of investment, the orientation of technological developmentand institutional change are all in harmony and enhance both current and future potential to meet human needs and aspiration. The concept according to Fri (1992), couples economic development and environmental that meets the needs of the present generation without compromising the ability of subsequent generations to meet their own needs (Toman, 1992). There are three basic components of sustainable development these are intergenerational fairness specification of the kind of social capital including both natural and human made resources to be sustained and the extent of human impact relative to the global carrying capacity.

\section{Approaches to sustainable development:}

- Global economic approach

- Environmental or ecological approach

Sustainable development is the entire combination of conditions and factors contributing to the maintenance or growth of incomes improved standard of living, well-being, its promotion thus depends on many aspects of economic activity and in particulars control population growth, encouragement of technical charge, optimal increase in the stock of factors contributing to the production of well-being, pricing of resources reflecting their relative scarcity, a change in the pattern of production and consumption in order to maintain the stock of scarce resources. Sustainability is the transmission or handling down of growth potential to future generations and in particular for the production of well-being.
From ecological approach, 2 elements are compared in the stock of capital which enables the maintenance of the potential growth of well being and that which must be transmitted to future generations. These include the stock of artificial capital or all the goods and factors of production created by human and natural capital or natural, renewable or non-renewable resources. On the basis of ecological approach to sustainable development the maintenance and transmission of a potential for growth and well-being require the application of management principles specific to each of these components of the overall capital each of which makes its own contribution to well being.

Sustainable development should therefore ensure that this natural capital is safeguarded and transmitted to future generationsand for several reasons:

- Certain resources are not renewable and are exhausted or lost immediately and this could lead to an extreme form of non-sustainability

- Natural resources are sources of well-being by virtue of the amenities supplied such as aesthetic features of a site; leisure; factors for health etc.

- Natural capital constitutes the very substratum of economic growth to which it contributes directly

- The existence of many uncertainties and in particular the possibilities for substitutions; irreversibility; the risks and thresholds of deterioration or exhaustion of resources; technical progress which would make it possible to compensate for the disappearance of certain natural resources; the taste and preferences of future generations

The phases of urban decay in Nigeria: A rapid increase in urban population results in the problem of straining or breaking down of sanitary facilities and other infrastructure in cities and towns. The local bodies are faced with the responsibility of providing amenities with limited or often scant resource. The net result of this incongruity between the resources and responsibility not only lead to formation of new slums but also gives new dimensions to the problem of slums (Deadline, 2003).

Slums are a formidable problem, merely because the gap between resources and demand for shelter tends to exist perpetually. Many slums are situated in vulnerable locations like river margins, water loosed areas and road margins etc. The slum population prefers to live in unhygienic conditions and in areas prone to floods and accidents. Besides, the problems of over-stretched infrastructures environmental degradation, seasonal flooding, destruction of national vegetation, all resulting from increase in population give rise to urban decay (Igbokwe, 2006). Urban decay can be described as the 
physicals effect including facilities that are poorly monitored and in disrepair, deterioration of buildings and improvements, visual and aesthetic impacts, increase in property crime and increased demand for emergency services which result from increase in retail closures and long-term vacancies (Environmental Impact Report, 2008). The built environment in many developing countries particular Nigeria is fast decaying (Ahianba et al., 2008). The factors responsible for this can be attributed to rapid urbanization, rural-urban migrationand decades of speedy economic downturn, decay of urban infrastructure and negligent urban housekeeping (World Bank, 2005).

Within the Nigeria contexts, the phases of urban decay are identified in the following areas which agree with features outlined elsewhere (Governance and Social Development Resource Centre, 2009):

\section{Environmental, health issues and living conditions}

Poor waste management: Rapid population growth in urban cities like Lagos, Ibadan, Onitsha, Kano, Kaduna, Awka, Port Harcourt etc has placed immense pressure on solid waste management systems. Solid waste is generated in almost all parts of the urban areas and solid waste management becomes complicated in bigger cities. In most cities/towns, the refuse is dumped in an unsatisfactory and haphazard manner without sanitary landfill. The failure of such systems to cope has contributed to water pollution, environmental degradation and the spread of communicable disease and fatalities.

Poor air quality: Air pollution is one of the key contributors to disease and fatalities globallyand is a significant problem in urban areas in Nigeria. The main sources are industrial plants, residential and commercial buildings, concentrations of hazardous waste and motor vehicles.

Environmental degradation: Rapid urbanization has resulted in deteriorating environmental conditions including from illegal occupation of open spaces, loss of tree cover, reclamation of water bodies and construction on river flood plains.

Inadequate urban utility services (water, sanitation and sewage, electricity, fuel etc): The cause of Nigeria urban decay can be attributed to the inadequacy and uneven distribution of service in the cities. Evidence of this scenario is shown when making a comparison with some selected countries in Africa. Table 2 shows the summary. Table 3 shows the distribution of households by type of toilet facilities (\%).
Table 2: Distribution of water and improved sanitation in Africa

\begin{tabular}{lcc}
\hline Countries & $\begin{array}{c}\text { Access to improved } \\
\text { water (urban) }\end{array}$ & $\begin{array}{r}\text { Access to improved } \\
\text { sanitation (urban) }\end{array}$ \\
\hline Nigeria & 78 & 66 \\
Ghana & 91 & 74 \\
Kenya & 88 & 96 \\
South Africa & 99 & 93 \\
Africa & 86 & 80 \\
\hline
\end{tabular}

Table 3: Types of Toilet in the urban household in Nigeria 2003 (in percentage)

\begin{tabular}{lll}
\hline Type of toilet & Nigeria & Urban sector \\
\hline
\end{tabular}

\begin{tabular}{lcc}
\hline Pit Latrine & 67.3 & 60.3
\end{tabular}

$\begin{array}{lll}\text { Water closet } & 21.1 & 36.2\end{array}$

\begin{tabular}{lll} 
Bush/stream/others & 11.6 & 40.0 \\
\hline
\end{tabular}

Table 3 further outlined the deficiency and inadequacy of basic infrastructural amenities in Nigeria urban centres (Ahianba et al., 2008).

Crime and insecurity: This is a major problem today in Nigeria urban centres. The proliferation of hooliganism, tuggery, criminality and other social vices have become eyesore in Nigeria. And this has been associated to the cause of:

Economic cost: Crime and violence in urban areas has been associated with various economic costs. These include: Costs related to medical treatment, foregone earnings, loss of productivity due to injuries, loss of competitiveness, losses through thefts and muggings, cost on private securityand costs to the judicial system.

Social cost: Crime and violence can also have significant non-monetary costs in terms of increased morbidity and mortality, erosion of social capital and higher levels of fear in trust and anxiety.

Poor productivity and market inefficiencies Informal and inefficient property markets: Uncertainty over land tenure and urban planning and management in many Nigeria cities has resulted in efficient operation of land and property markets, excessive speculation and high levels of dispute and litigation in the cities. The property market is characterized with infiltration of quacks in Benin, Lagos, Ibadan, Port Harcourt, Kano etc.

Limited incentives: Urban workers who are self-employed or working in low paid informal jobs are often unable to earn more, regardless of their efforts which can undermine productivity.

Fragmented production chains: High rent in urban centres has resulted in the location of suppliers away from producers. This can result in inefficient supply chains 
distribution structure and high local transaction costs in manufacturing industries. This is similar to the cases in Asia (Governance and Social Development Resource Centre, 2009).

Housing problem: Quantity and quality: This has remained an unresolved problem in the cities. Substandard housing in Nigeria urban centres is a major problem of the cities. The problems of most of the urban cities like Lagos, Ibadan, Kano, Enugu and Benin City etc., resulted from the fact that they were never planned by experts (Ahianba et al., 2008). The problem is particularly serious for those in the lower-income strata.

Traffic congestion: The rapid expansion of cities and improper transport planning has produced significant traffic congestion in Nigeria cities. This has resulted in financial costs for urban residents due to lengthy travel times to work and time wasted and higher transaction costs to business in moving goods and services.

The foregoing situations have made the urban areas breeding places for crimes and defiant behaviours thus, making the urban centres unsafe for people, unattractive to investors, unconducive to economic activities and inimical to good governance.

\section{RESULTS AND DISCUSSION}

Issues of urban renewal or eedevelopment for urban sustainability in Nigeria: Berg opined that urban regeneration is an issue that has raised up the policy agenda of European member states since the mid 1990's. It is being increasingly recognized that cities are the motors of regional economic growth within the European Union (EU) and often the location of significant prosperity.

The basic idea behind urban renewal is simple future tax revenues pay for revitalization efforts. Urban renewal areas usually show evidence of some degree of blight, demonstrated by conditions such as poorly constructed buildings, faulty planning, lacking open spaces, deteriorated properties, an incompatible mix of uses and improper utilization of land. Huan stated that the best strategy for sustainable urban development and to limit urban decay is care for existing cities. This is especially a challenge in rapid urbanizing countries like Nigeria. As put it by Emordi and Osiki (2008), the houses are drab, dirty and recking with unclean and decaying refuse. Water is scarce and must therefore be rationed, excreta disposal is inadequate with litters of human waste being a common sight in a neighbourhood (there) are inadequate drainage facilities with waste water forming mini puddles within the compound where mosquitoes and insect vectors exercise their reproductive potentials. The situation agrees with the conclusion that most of the cities in Nigeria demonstrate the gradual villagization as a result of population explosion, environmental degradation and the inability of the various governments and urban councils to control the growth of cities (Emordi and Osiki, 2008). Urban renewal or redevelopment has been considered as a tool to solving the problem of squatter settlement (Aluko and Amidu, 2006).

Urban renewal theories were largely influenced by social, economic and historical developments as well as city planning movements immediately after the Second World War (WWII). Many countries embarked as rebuilding efforts, characterized by demolition of old dilapidated areas, large-scale clearance of city slums and construction of modern high-rises after the war. Large-scale redevelopment created many social problemsand encouraged many city planners and scholars to question its effects and functionalities. Indeed, large scale renewal and redevelopment efforts have been criticized for neglecting the complexities of the urban fabric; it is not only uneconomical but also damages the city's heritage and degrades various socio-environmental qualities.

Urban renewal process is increasingly expensive as the redevelopment process involves not only building new structures but also resetting the original residents. As described by Waque and Hirji (2005), urban intensification produces a diversity of densely packaged, highly valued economic interests in real estate in terms of fee simple interests, limited partnerships, ground leases, retail leases, joint ventures, mortgages and etcetera.

According to Olusule, five procedural steps are necessary to be followed to accomplish a desirable urban renewal exercise for the community. They are acquisition of land in accordance with the plan, relocation of residents from the acquired building into satisfactory quarters, site clearance the razing of the structures on the land may be carried out only after the quality of such structures have been determined, site improvements and supporting facilities and services are undertaken by the agency and land may be built upon by agency or sold to original owners if compensations have been paid.

Urban renewal has also been linked with the sustainable provision of basic amenities such as water and electricity (Van der Bruggea and de Graff, 2010; Zeeman and Lettinga, 1999; Newman, 2001; Ashley et al., 2004). The provision and continuous management of amenities are fundamental to the concept of sustainable urban development. 
In African urban housing in the $50 \mathrm{~s}$, two of the hallmarks of the colonial approach were the redevelopment of decaying core areas combined with the renewal of slums or squatter areas and the construction of large rental (sometimes tenant purchase) public housing estates. At the start, the minister of Lagos Affairs appointed the Lagos Executive Development Board (LEDB) in 1951, now known as the Lagos State Development and Property Corporation (LSDPC) to clear a slum area of about 28.34 ha ( 70 acres) in central Lagos within a triangle in the variety of Broad Street Balogun and Martins Streets together with Nnamdi Azikwe street and the area east of it. The sum of N5.90 million was granted by then government to the LEDB for the clearance of the slum but actual expenditure in 1962 had risen to about N6,932,886 despite the little cleared (Aluko and Amidu, 2006). The amount of deposits received by government from lots redeemed, amounted to only N1, 452.192 leaving a net balance of expenditure of N5, 476,694. Land acquisition and structures, apart from the Surulere rehousing site amounted to about N6,232,360.

Furthermore, it is pertinent to state that various actions of urban renewal programmes have been constraint with public criticism. However, various factors have been considered as the motivators of the exercise; poor drainage, poor environmental conditions, transport congestion etc. Adequate provision of basic facilities such as electricity, water supply, good roads school and other services is refund to entire the functioning of the any urban neighbourhood as well as for the stability and development of individual family life (Agbola and Jinadu, 1997).

Urban renewal strategy: Urban renewal process is perceived to overhaul the congestion in the city centres (Andersen and Engelstoft, 2004; Lichtenberger, 1994; Vidfor, 2007). Urban renewal comprises some numbers of strategies such as Filtration, social planning, the boot-strap strategy, replacement, guiding urban growth through investment and local government strategy (Balchin and Kieve, 1977).

Filtration is based on the out-migration of households and employment followed by the clearance and redevelopment of vacated sites. It was potentially the most system-oriented of the approaches. Out-migration resulted from both planned decentralization and market forces. This is achieved with the creation of new towns to provide overspill housing and employment to eliminate difficult journeys to work. It can also be in the form of expanded towns or satellite towns. The expanded towns received even less overspill than the new towns. Webster (2004) underlines the importance of peripheral development around metro cities. He argues that in case of fast growing urban centres, peri-urban areas have experienced rapid economic growth as that is the easiest environment in which new communities and manufacturing structures can be built, absorbing large numbers of migrants. This approach however, calls for the resuscitation of new town creations in the time past in Nigeria such as satellite town, Lagos; Ajoda New Town, Ibadan etc.

Social planning, as described by Balchin and Kieve (1977), governments have regarded this as being secondary to physical and economic planning. Social planning focuses on people rather than on urban space or propertyand should first involve analyses of the basic causes of deprivation as a prelude to the application of needs-related policies.

The boot-strap strategy entails rehabilitation and is mainly confined to housing. It does not (or should not) involve the displacement of occupant and it is often thought that in economic terms, it is less costly than redevelopment, although evidence is conflicting. Needleman's renewal theory thus suggested that the comparative economics of redevelopment and rehabilitation depends on:

- The rate of interest

- The future life of the rehabilitated property

- The differences between the running costs of the new and rehabilitated property. Normally, rehabilitation would be worthwhile if the present cost of clearance and building exceeds the sum of the cost of rehabilitation, the present value of the cost of rebuildingand the present value of the difference in annual running costs

Mathematically rehabilitation would be more economic than redevelopment if:

$$
\mathrm{b}>\mathrm{m}+\mathrm{b}(1+\mathrm{i})^{-\lambda}+\mathrm{r}\left[1-(1+1)-^{\lambda} \mathrm{I}\right.
$$

Where:

$\mathrm{b}=$ Cost of demolition and rebuilding

$\mathrm{m}=$ Cost of rehabilitation

$\mathrm{I}=$ The rate of interest

$\lambda=$ Useful life of the rehabilitated property in years

$r=$ Difference in annual repair costs

Further researches in the model seemed to suggest that rehabilitation was cheaper than redevelopment, although the question of timing have been ignored.

Replacement: Here clearance is followed by sound redevelopment schemes. Usually there are many social 
problems that need to be solved especially if redevelopment does not occur immediately after clearance, therefore it is essential that not just for economic reasons, schemes are carefully selected, priorities determined and work sensitively programmed (Harvey, 1978, 2000). Development is undertaken by either the public or private sector or by a partnership of both. This approached had been adopted both in the US and UK.

Guiding urban growth through investment: This method combines the replacement strategy with market forces. Areas are initially ranked according to their renewal potential, related infrastructure might be improved and private investment is attracted.

Challenges of urban renewal for sustainable urban development in Nigeria: Cities have to find out how to reduce the risks inherent in the tendency of contemporary urban societies to fall back on their heritage and roots as they face up to an identity crisis. This implies that innovation in urban space design represents an opportunity to construct a good identity of places and give an international scope to the urban form of cities (Sepe, 2006).

The goal of environmental sustainability is to minimize environmental degradation which is the damage to the biosphere as a whole due to human activity. An unsustainable situation occurs when natural capital (the sum total of nature's resources) is used up faster than it can be replenished (Agbola and Agunbiade, 2007). Sustainability requires that human activity, at a minimum, only uses nature's resources at a rate at which they can be replenished naturally.

However, there are a multitude of reasons why urban renewal in general specifically in the Nigeria cities and often not fully integrated into more traditional urban planning. Among the most important reasons are:

The urbanization process itself (Clark, 2009): The rapid pace of urbanization places an enormous burden on the planning process i.e., planning for renewal, new development and upgrading of the existing urban environment.

Urban governance and planning: The negative impact of weak governance and the difficulty of transforming political will into action is a factor.

The structure of urbanization: The process and the resulting spatial form of urbanization is a function of many factors and are arguably different for each urban centre.
With variations however, there is a general consensus that the process becomes more integrated as the urban center develops and the spatial form of growth can be broadly classified as concentric, sectional or multiple nuclei in form. In urbanizing Lagos metropolis the rapidly emerging new urban centers are primarily following the multiple nuclei development. This is particularly making urban renewal programme difficult.

Lack of adequate institutional and legal framework within which community safety and settlement strategies fit.

Institutional resistance to change and new approaches to tackling land use, crime sanitation and urban renewal process.

Lack of effective framework to ensuring truly inclusive participation and partnership in the development and delivery of sustainable community safety strategies and interventions. Such as: locally-based approach (defined neighborhoods):

- Citizen participation (residents, stakeholders)

- Comprehensive approach (problems are seen as interrelated across a range of issues and to include social economic and physical issues)

- Collaborative public-private partnerships (residents, corporations, community organizations, local government)

- Consensus orientation, working in partnerships (rather than confrontation)

- Community-building through partnerships

Lack of adequate information on the value and place of urban renewal in urban planning (Clark, 2009).

Public specific concerns about development density, urban design (e.g., building height, local characteristics and public spaces), environmental protection and public transport considerations during the urban regeneration process.

Emphasis on people-centred approach i.e., the relation between development and quality of lifeand the importance of preserving and revitalizing social network, local culture and heritage as well as local economy instead of cities physical renewal.

Compensation, rehousing and resumption: Emphasis and expectation to offer owners and tenants more options of compensation and rehousing, like shop for shop and flat for flat rehousing in the same area. Social impact inability to expand the scope of social impact assessments look at both social benefits and social costs before and after the redevelopment. 
Expensive cost of renewal: Urban renewal process is increasingly expensive as the redevelopment process involves not only building new structures but also resetting the original residents. At times the amount of compensation and relocation can reach $80-85 \%$ of the court of redevelopment.

Weak groups: Part of the population of the historic district in aging, poor and care should be provided both for affordable housing and public amenities.

Ownership: The majority of the buildings is owned by corporations, both private and public or combinations. Small ownership is scarce making it unattractive for individuals to invest in improvements.

Lack of commitment from community members and poor communication on the community participation process and this led to poor meeting attendance.

An urban sustainability can therefore be likened to an urban ecosystem which is referred as a composite of the natural environment, the built environment and the socio economic environment (Clark, 2009). The land area and resources that must be used to sustain a population demands, sustainable utilization and management.

\section{CONCLUSION}

As stated (Ademiluyi and Solanke, 2008), Nigerian Urban centers are faced with numerous problems so complex are these problems that they (urban centres) can be described as an increasingly important stages on which all aspects of the human drama are performed; the highest learning and the grossest ignorance, unimaginable levels of wealth and the most abject poverty exists side by side.

Urban areas in Nigeria depend on natural resources for water, foods construction materials, energy and the disposal of wastes. Urbanization will not however, deliver its benefits for sustainability automatically; they require careful preparation and nurturing.

Thus revitalization of city centres calls for implementation in Nigeria. Restoring vitality to urban centres means designing centres of attracting. It means offering more and different reasons to come to the city. It also means offering a space that can be used by different groups of people with different needs each that can find satisfaction.

The above discussion and measure are fundamental to ensure efficient urban renewal that can transform our cities in Nigeria.

\section{RECOMMENDATIONS}

The interaction between urbanization and natural resources underlines the need for renewal for sustainability. Perhaps for the Nigerian urban centres to be healthyand sustainable, the extent of urban decay needs to be investigated and renewal approaches should be identified as done in this study.

Urban renewal or redevelopment can be a useful tool to facilitate the transformation of Nigerian cities. Effect of UNDP and World Banks-Assisted projects on urban renewal in Nigeria cities recently have delivered a commendable dividend in Nigeria.

However, in order to ensure sustainable urban development, it is important to take note of the following issues for implementation among others. Proper education and enlightenment of people on issues of urban renewal:

- Involvement of private public partnerships-NGOs

- Private firm or agency

- Adoption and renewal of the ideas of new towns and satellite towns in Nigeria

- Development of rural areas and provision of infrastructure

- Creation of job and enabling environment for youths

- Inauguration and empowerment of urban management taskforce

- Effective regulation for housing standard approval.

- Provision of low-cost and low-income housing for the needy population

- Enforcement of code of conduct in the built environment

- Adequate compensation of the owners of dispossessed properties marked for clearance

- Emphasizing sustainability in infrastructure design and planning in a way that will foster human activity and support economic growth without hindering the environment

- Utilizing the wealth of management techniques and expertise gained from previous urban developments to coordinate and manage the new development efficiently

- Using advanced technologies (both in materials and information technology) to optimize the overall provision and management of the new facilities such as GIS

- Institutional framework: This include-Institutional arrangements in formulating and implementing urban renewal policies. Statutory and executive power of implementation agencies and its composition of the board and public accountability. The Land law and administration related to land ownership/tenure in the context of planning and redevelopment, the policy approach and powers to enable property acquisition or resumption. Compensation and rehousing policies 
- Financing models of urban renewal, financial arrangement of implementation agenciesand other financial instruments (e.g., tax relief or tax incentives)

- Relative emphasis on different types of urban renewal (i.e., redevelopment, rehabilitation, revitalization and preservation)

- The use of social impact assessment

\section{REFERENCES}

Adelekan, I.O., 2004. Vulnerability of poor urban coastal communities to climate change in Lagos, Nigeria. Proceedings of the 5th Urban Research Symposium, (URS'95), Lagos, Nigeria, pp: 1-18.

Ademiluyi, I.A. and M.O. Solanke, 2008. Perceptual notion and realities of Nigeria urban centres. Pak. J. Soc. Sci., 5: $177-181$

Agbola, T. and A.M. Jinadu, 1997. Forced eviction and forced relocation in Nigeria: The experience of those evicted from Maroko in 1990. Environ. Urbanizat., 9: 271-288.

Agbola, T. and E. Agunbiade, 2007. Urbanization, slum development and security of tenure: Proceeding of the PRIPODE Workshop on Urban Population, Development Countries, June 11-13, University of Lagos, Nigeria, Nairobi, Kenya, pp: 1-22.

Ahianba, J.E., K.O. Dimuna and A. Okogun, 2008. Built environment decay and urban health in Nigeria. J. Hum. Ecol., 23: 265-265.

Akinbode, I.A., 1995. Sustainable development in rural Nigeria: An agenda for suspended republic. Proceedings of the National Research Service Award Nigeria.

Alao, J.A., 1995. Sustainable rural development for rural transformation: A plea for relevance. Proceedings of the 8th Annual Conference of Nigeria Rural Sociological Association, (NRSA'95), Rural Sociological Association Nigeria, pp: 119-131.

Aluko, B.T. and A.R. Amidu, 2006. Urban low income settlements, land deregulation and sustainable development in Nigeria. Proceeding of the 5th FIG Regional Conference Promoting Land Administration and Good Governance, March 8-11, Accra, Ghana, pp: $1-12$.

Andersen, H.T. and S. Engelstoft, 2004. The end of urbanization? Transformation of the urban concept. Dela, 21: 53-67.

Ashley, R., D. Blackwood, D. Butler, J. Davies, P. Jowitt and H. Smith, 2004. Sustainable Water Service: A Procedural Guide (SWARD). IWA Publishing, London, UK.

Balchin, P.N. and J.L. Kieve, 1977. Urban Land Economics. 1st Edn., MacMillan, London, ISBN: 0333180836.
Clark, A.L., 2009. Environmental challenges to urban planning: Fringe areas, ecological footprints and climate change. Proceeding of the Workshop in Governance, Socio-Economic and Environmental Issue. Sept. 16-18, Ho Chi. Minh City, Vietnam, pp:1-8.

Deadline, A., 2003. Tamil Nadu, an Economic Appraisal. Evaluation and Applied Research Department, Finance Dept., Tamid Nadu, India.

Emordi, E.C. and O.M. Osiki, 2008. Lagos: The Villagised city. Inform. Soc. Just., 21: 95-109.

Environmental Impact Report, 2008. Urban decay. Draft Report, City of San Rafael. http:/www.city ofsanrafael.org/Assets/CDD/Planning/Urban+Decay. pdf.

Fri, R.W., 1992. Questions that seem Important. Resources, 107: $15-17$.

Gomez, F. and P. Salvador, 2006. A proposal for green planning in cities. Int. J. Design Nature, 1: 91-109.

Gospodini, A., 2002. European cities and place-identity. Discuss. Paper Ser., 8: 19-36.

Gospodini, A., 2004. Urban space morphology and place-identity in European cities: Built heritage and innovative design. J. Urban Design, 9: 225-248.

Governance and Social Development Resource Centre, 2009. Helpdesk research report: Costs of urbanisation. http:/www.gsdrc.org/docs/open/HD637.pdf.

Harvey, D., 1978. The urban process under capitalist: A framework for analysis. Int. J. Urban Regional Res., 2: 101-131.

Harvey, D., 2000. Urban Land Economics. 5th Edn., Palgrave Publishers Ltd., New York, pp: 270-275.

Igbokwe, J.I., 2006. Mapping and spatial characterization of major urban centres in parts of Southeastern Nigeria with NigeriaSat-1 imageries. Proceedings of the 5th Regional Conference of International Federation of Surveyors (FIG), March 8-11, Acrra, Ghana, pp: 1-23.

Lichtenberger, E., 1994. Urban decay and urban renewal in budapent and vienna a comparison. Acta Geograph. Lovaniensia, 34: 469-477.

Mabogunje, A.L., 1980. The Development Process: A Spatial Perspective. Hutchinson University Library, London, pp: 382.

McGianahan, G., D. Balk and B.C. Anderson, 2007. The rising tide: Assessing the risk of climate change and human settlements in low elevation coastal zones. Environ. Urbanizat., 19: 17-37.

Newman, P., 2001. Sustainable urban water systems in rich and poor cities-steps toward a new approach. Water Sci. Technol., 43: 93-99.

Oyesiku, O.O., 1997. The new cities as a physical planning strategy Concept. Understand. Nig. J. Social Manag. Sci. 1: 76-101. 
Phillip, M.A. and F.S. Leo, 1985. Study of Urbanization. John Whiley and Sons, Inc., New York.

Sepe, M., 2006. Complex analysis for the sustainable planning and construction of the place identity: The sensitive relief method. Int. J. Ecodynam., 1: 14-31.

Spates, J.L. and J.S. Macionis, 1987. The Sociology of Cities. 2nd Edn., Wadsworth Inc., United States, ISBN: 0534072542 , pp: 514.

Terradas, J., 2001. Ecologia Urbana. Rubes Editorial, Barcelona, Spain, pp: 127.

Toman, M.A., 1992. The Difficulty in Defining Sustainability. In: Global Development and the Environment: Perspectives on sustainability, Darmstadter, J. (Ed.). RFF, Washington, DC., pp: $15-24$.

UN and UNCHs, 2010. Urbanization and global environmental change. Proceeding of the 1 st International Conference on Urbanization and Global Environmental Change "Opportunities and Challenges for Sustainability in an Urbanizing World, Oct. 15-17, Temple, A.Z., USA., pp: 1-3.
Van der Bruggea, R. and R. de Graaf, 2010. Linking water policy innovation and urban renewal: The case of Rotterdam, The Netherlands. Water Policy, 12: 381 400.

Vidfor, J., 2007. Is urban decay bad? Is urban revitalisation bad too? Social Science Research Network. Paper No. INS. 12955. US

Waque, S.F. and S.M. Hirji, 2005. Urban renewal land assembly: Where do we grow from here. International Right of War Association, Chapter 29, October 14th 2005. http://www expropriation.com/Cases/Urban_ Renewal_Land_Assembly.pdf.

Webster, D.R., 2004. Urbanization Dynamics and Policy Frameworks in Developing East Asia. The World Bank, East Asia Infrastructure Department, Washington.

World Bank, 2005. Global Strategy and Booster Programme. World Bank Publications, Washington, D.C., USA., ISBN: 0821361996, pp: 193.

Zeeman, G. and G. Lettinga, 1999. The role of anaerobic digestion of domestic sewage in closing the water and nutrient cycle at community level. Water Sci. Technol., 39: 187-194. 